\title{
マイナスイオン発生量からみた A STUDY ON THE AQUA SCAPE FACIL- 水景施設の評価 ITIES IN VIEW POINT OF MINUS ION
}

$\begin{array}{ll}\text { 磯部久貴 }-* 1 & \text { 畔柳昭雄 }-* 2 \\ \text { 渡辺秀俊 }-* 3 & \text { 二宮 敦 }-* 4\end{array}$

キーワード

マイナスイオン, 水景施設, 心理構造, 物理的外的要因

Keywords :

Minus ion, Aqua scape facilities, Psychological structure, Physical outward factor

\section{Hisataka ISOBE —_- $* 1$ \\ Akio KUROYANAGI $-* 2$ \\ Hidetoshi WATANABE $-* 3 \quad$ Atsushi NINOMIYA $-* 4$}

It studied to the object in the Aqua scape facilities in Tokyo.

Then, it examined psychological structure in the Aqua scape facilities in examining a physical outward factor at the Aqua scape facilities. It examined Minus ion as the center of the physical outward factor. The psychological structure and the physical outward factor depend on the form of the Aqua scape facilities. Minus ion depended on the form of the Aqua scape facilities mainly. Between the psychological structure and the physical outward factor, relation is seen. Minus ion was related to the property of water.

\section{1.はじめに}

水環境に対して 1970 年代に「親水」という概念が提起されて 以来，都市空間のアメニテ价高めるものとして、水や水辺並びにウ オーターフロントに対する関心が高まってきている。また、1980 年 代以後, 水辺においては親水機能を備えた施設整備が盛んになり、 合わせて都市公園についても噴水や池など水景施設を整備するもの が増えてきた。中でも，水景施設は空間演出的な役割と共に，水面 の動きや音、光の反射など視覚的な環境特性を保有し、さらに水面 の持つ微気候調節効果などにより快適性の創出にも寄与している。 この中で, 水の音の効果については、鈴木らによって「水音環境」 に着目した技術報告 ${ }^{1)}$ がなされている。

このような現状の中で水景施設における新たな物理的評価指標と してマイナスイオンの発生量に注目した。これは、水景施設を作り 出している水が、噴き出したり流れ落ちたり動いたりすることによ って水が飛沫すると、大気中に水の微粒子が浮遊しエアロゾルが発 生する。これにマイナスの電子が帯電するとマイナスイオンとなり、 人間の副交感神経を鎮め，生理的、心理的にリラックスさせる効果 があるとされている。しかし，その存在量が多いとされている水景 施設において、その効果は充分に把握されていない。一方、マイナ スイオンについては、これまで研究 2) 31) 4) の蓄積が少なく, マイナス イオンが人間にもたらす影響に対しては十分に把握されてはいない。

\footnotetext{
*1 侏)八下代エンジニヤリング

(干153-0043 目黑区東川2-2-3-902)

*2 H本大学理工学部海洋建築- - 学科 助教授・丁博

*3 二洋テクノマリン L博

*4 日本大学大学院理上学研究科 海洋建築厂学尃攻
}

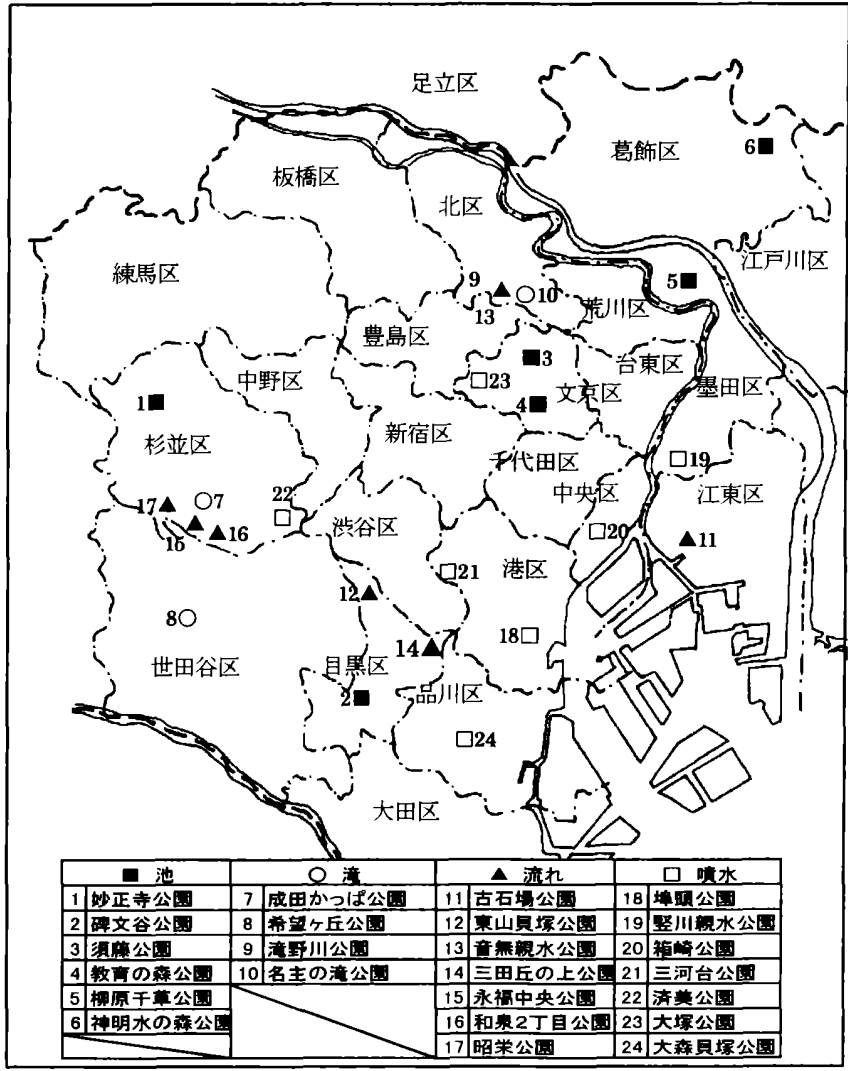

図-1 研究対象地

*1 Yachiyo Engineering Co., Ltd. M. Eng.

*2 Assoc. Prof., Dept. of Oceanic Architecture and Engineering College of Science \& Technology, Nihon Univ., Dr. Eng.

*3 Sanyo Techno Marin Inc., Dr. Eng.

*4 Graduate School, Nihon Univ. 


\section{2. 研究目的}

本研究は、水景施設によって発生するマイナスイオン量につい て計測するとともに、これを感じ取る人々の心理的評価も併せて調 查し、その効果を明らかにすることを目的とする。そこで，親水公 園に打ける水景施設を対象とし，以下に示す 3 点について検討寸る。

(1)マイナスイオンの発生量の把握

（2）水景施設に対する心理的評価構造の把握

（3）心理的評価構造とマイナスイオン発生量との関連性の把握

\section{3. 研究方法}

本研究は、東京都特別区における親水公園を対象とした。水景

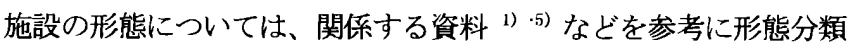
を行い、池、滝、流れ、噴水を保有する公園の中から図-1 に示寸 24 公園を選定した。これらの対象公園において，表一 1 に示寸調 査を行った。マイナスイオンの計測はイオンカウンタ（ダン科学製 83-1001）を用い，既往文献6・㠩から人間に影響をおよぼすとされる 電気移動度 0.4 以上のマイナスイオンを測定対象とした。併せて気 温，水温，湿度を測定した。また，公園面積に占める水景施設の水 面積及び周辺の緑の面積の割合を水面率、緑被率として計測した。 さらに、公園利用者を対象として、水景施設から受ける人々の感受 度を捉えるため関連する既往研究 ${ }^{8)}$ 等を参考として、項目の付加 ・ 整理を行い選定した 18 項目 5 段階の評定尺度によるアンケート調 查を実施した。なお、被験者抽出は水景施設の周辺でランダムサン プリング法により実施した。

\section{4. 心理的評価構造の調查結果}

アンケート調査を基に、水景施設に対する潜在的な心理構造を 把握するために因子分析を行った。その結果を表一2 に示す。第IV 因子まで抽出され，累積寄与率は $67.2 \%$ あっあた。

各因子の意味を因子負荷量 0.45 以上のものから解釈すると，第 I 因子は「緑の量」「緑の種類」「自然」などの因子負荷量が高く， 「自然性」を示寸因子と考えられる。次に，第洇子は「水量」「水 のきれいさ」「水面積」といった項目の因子負荷量が高く「水の審 美性」に関する因子といえる。また、第皿因子では「涼しさ」「開 放感」などの因子負荷量が高く，「空間性」を表す因子と考えられ る。最後に第下因子では「水の深さ」「水までの距離」「水面積」の 因子負荷量が高く，「水の規模性」を表す因子といえる。

次いで、形態別に得られた因子得点を平均化し，その結果を図 - 2 に示す。まず「池」は I 軸と而軸、IV軸の因子得点が高く，規 模性が強く認識されている。次に「滝」では「池」と逆にロ軸の因 子得点が高く，IV軸の得点が低い。このことは，「滝」の持つ水の 動きから審美性が認識されていると考えられる。「流れ」は，すべ ての因子得点が低いが概权「滝」のパターンと類似している。最後 に「噴水」では，I 軸の因子得点が極端に低いが，その他の因子は 高く，水の保有する特性が認識されていると考えられる。
表 -1 調査概要

\begin{tabular}{|c|c|c|c|}
\hline \multicolumn{2}{|r|}{ 調査内容 } & 項 目 & 内 容 \\
\hline \multirow{2}{*}{\multicolumn{2}{|c|}{ 調査対象 }} & 対象公園 & $\begin{array}{l}\text { 池・滝・流れ・噴水の形態を持つ親 } \\
\text { 水公園計 } 24 \text { 公園 }\end{array}$ \\
\hline & & 調査期間 & 1997年8月 1 日〜10 日(快晴) \\
\hline \multirow{4}{*}{$\begin{array}{l}\text { 心 } \text { 理 } \\
\text { 要 } \\
\text { 要 }\end{array}$} & \multirow{4}{*}{ アンケート } & 対象者 & 18 才以上の公園来訪者 \\
\hline & & 調査方法 & 対面調査 \\
\hline & & 標本数 & 720 (各公園 30 回収率 100\%) \\
\hline & & 質問内容 & 水から受ける感受度及び被験者属性 \\
\hline \multirow{8}{*}{$\begin{array}{l}\text { 物 } \\
\text { 理 } \\
\text { 的 } \\
\text { 要 }\end{array}$} & \multirow{3}{*}{$\begin{array}{l}\text { マイナス } \\
\text { イオン }\end{array}$} & 計測機器 & 仏加六 83-1001 \\
\hline & & 計測方法 & $\begin{array}{l}\text { 水景施設中央に最接近できる地点で } \\
\text { 上地上から } 1.5 \mathrm{~m} \text { にや訳を設置 }\end{array}$ \\
\hline & & 計測時間 & エ价ング後 30 分計測 \\
\hline & \multirow{2}{*}{ 水温 } & 計測機器 & 水銀水温計 \\
\hline & & 計測方法 & 水景施設内の水温を計測 \\
\hline & \multirow{2}{*}{ 気温/湿度 } & 計測機器 & 乾湿球温湿度計 \\
\hline & & 計測方法 & 仏功外付近で計測 \\
\hline & $\begin{array}{l}\text { 水面面積 } \\
\text { 緑被面積 }\end{array}$ & 計測方法 & $\begin{array}{l}\text { Auto CAD Ltによる図面を用いた面 } \\
\text { 積計測 }\end{array}$ \\
\hline
\end{tabular}

表一2 因子分析結果（ソート後）

\begin{tabular}{|c|c|c|c|c|c|}
\hline & & 第 I 因子 & 第 II 因子 & 第而因子 & 第IV因子 \\
\hline & 緑の量 & 0.0004 & -0.055 & -0.221 & -0.205 \\
\hline & 緑の種類 & $\frac{0.867}{.07}$ & -0.162 & -0.154 & -0.086 \\
\hline & 木陰の量 & 0.834 & -0.054 & -0.257 & -0.107 \\
\hline 軸 & 自然 & 0.810 & 0.046 & -0.416 & 0.098 \\
\hline & 風の心地よさ & 0.667 & -0.054 & 0.585 & -0.087 \\
\hline & 空気のきれいさ & 0.628 & 0.296 & -0.334 & 0.094 \\
\hline & 生物の多さ & 80.0664 & -0.105 & -0.283 & 0.386 \\
\hline & 水量 & 0.142 & $=0.770$ & -0.215 & 0.391 \\
\hline & 水のきれいさ & -0.146 & $=0.762$ & -0.242 & -0.401 \\
\hline II & 水面積 & 0.240 & 10.01 & -0.015 & 0.01326 \\
\hline 軸 & 透明度 & -0.269 & 1010.6 & -0.248 & 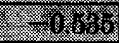 \\
\hline & 水景施設のデザイン & 0.035 & -.0091 & 0.061 & -0.262 \\
\hline & 快適 & 0.456 & 20.1174 & 0.168 & 0.050 \\
\hline & 涼しさ & 0.421 & -0.083 & .0 .364 & -0.004 \\
\hline III & 開放感 & 0.436 & 0.360 & 0.0589 & -0.167 \\
\hline & 乾湿感 & -0.133 & 0.410 & 20.488 & 0.076 \\
\hline IV & 水の深さ & -0.267 & 0.032 & -0.062 & 0.662 \\
\hline 軸 & 水までの距離 & -0.144 & 0.192 & 0.207 & 0.812 \\
\hline & 有值 & 5.226 & 3.247 & 2.356 & 1.939 \\
\hline & 率 (\%) & 27.5 & 17.1 & 12.4 & 10.2 \\
\hline & 責寄与率 (\%) & 27.5 & 44.6 & 57.0 & 67.2 \\
\hline
\end{tabular}

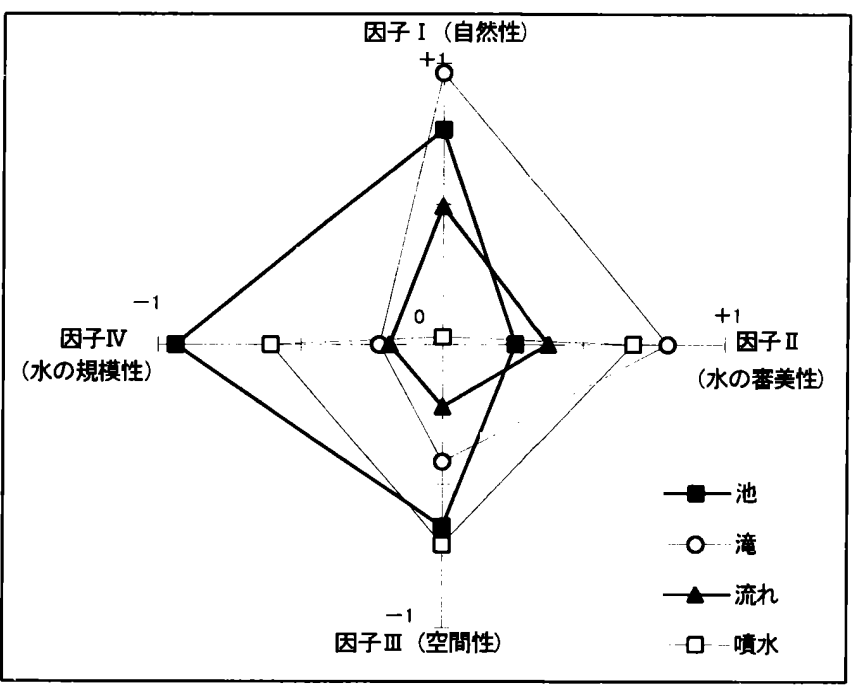

図-2 形態別因子得点 


\section{5. マイナスイオン量等の測定結果}

マイナスイオン量は、既往研究 ${ }^{3) \cdot 4}$ によると通常の大気中には約 $0.1 \sim 0.2 \times 10^{3} \mathrm{n} / \mathrm{cc}$ の存在量があると指摘されている。そのため、 各水景施設を計測するとともに、参照値として日本大学船橋校舎内 でアスファルト上と芝生上についても併せて計測を行った。

その結果を表一 3 に示す。まず，大学内におけるアスファルト上 3 ヶ所のマイナスイオン量の平均值では $0.21 \times 10^{3} \mathrm{n} / \mathrm{cc}$ を示し, また芝生上では $0.28 \times 10^{3} \mathrm{n} / \mathrm{cc}$ の值を示した。このことから若干で はあるが植生周辺では, アスファルト上よりもマイナスイオン量が 多いことが分かる。また、各水景施設における計測結果を見ると，

概ねマイナスイオンの存在量の多いことが分かる。

一方，気温，水温，湿度との関連性については際立った関係は みられない。

次に水景施設形態ごとのマイナスイオン存在量をみると,「滝」 が最も多く, 4 公園平均で $14.4 \times 10^{3} \mathrm{n} / \mathrm{cc}$ の值を示している。しか し、滝の落差の規模が小さい成田かっぱ公園では、他と比べて少な くなっている。次いで、「噴水」および「流れ」となる。「噴水」は 平均值で $3.29 \times 10^{3} \mathrm{n} / \mathrm{cc}$ の值を示し，「流れ」では，平均值は 0.87 $\times 10^{3} \mathrm{n} / \mathrm{cc}$ を示す。水の動きの少ない「池」でも平均值 $0.92 \times 10^{3} \mathrm{n} / \mathrm{cc}$ を示しており、水の飛沫が発生しやすい形態の水景施設においてマ イナスイオンが多く発生していることが分かる。一方、類似の形態 でも発生するマイナスイオン存在量に大きな開きのあることが分か る。そこで、周辺環境として、緑量との関係についてみると、マイ ナスイオン存在量が高い值を示す公園では比較的緑被率が高く、水 際線にも濃密な植生が見られ、水中にはアシやヨシが繁茂していた。 逆に，低い值を示す公園では水景施設周辺の植生は極めて少ない。 これらのことから，図一 3 に示すマイナスイオンと緑被率の関係を みると、僅かではあるが関係性がみられ、マイナスイオン存在量に 対して植生の存在が影響していることも考えられる。

\section{6. 物理的要因と心理的評価の関係}

水景施設に関連する物理的要因と心理的評価構造との関連を把握 するために，マイナスイオン量，緑被率及び水面率と，感受度を構 成している 4 つの因子軸の各因子得点を比較検討することとした。 なお、因子得点は因子分析で得られた值を 10 階級の因子階級に分 けて用いている。

その結果, 図一 4 に示すように、第 I 因子「自然性」は緑被率と の間で関連がみられ、緑被率が高くなるほど概ね因子階級も高くな る傾向がみられた。次に図一 5 に示すように、第几因子「水の審美 性」はマイナスイオン存在量との関連性については際立った関係は みられない。その中で、形態ごとの平均值で分布傾向をみると、「流 れ」については評価が比較的分散していることが分かる。また、 「池」、「流れ」に比べ、「滝」、「噴水」は若干ではあるがマイナス イオン量が増えると感受度も高くなる傾向がみられる。
表 -3 マイナスイオン等の計測結果

\begin{tabular}{|c|c|c|c|c|c|c|c|}
\hline 形 & 公 園 名 & $\begin{array}{l}\text { マ } 1 \text { †年ion } \\
\left(10^{3} \mathrm{n} / \mathrm{cc}\right)\end{array}$ & $\begin{array}{c}\text { 気温 } \\
\left({ }^{\circ} \mathrm{C}\right)\end{array}$ & $\begin{array}{c}\text { 水温 } \\
\left({ }^{\circ} \mathrm{C}\right)\end{array}$ & $\begin{array}{c}\text { 湿度 } \\
(\%)\end{array}$ & $\begin{array}{c}\text { 緑被率 } \\
(\%) \\
(\%)\end{array}$ & $\begin{array}{c}\text { 水面率 } \\
(\%)\end{array}$ \\
\hline 比 & アスファルト & 0.21 & 22.0 & - & 74.2 & - & - \\
\hline 較 & 芝生 & 0.28 & 19.9 & - & 83.4 & - & - \\
\hline & 妙正寺公園 & 0.31 & 27.9 & 27.8 & 74.9 & 34.8 & 25.1 \\
\hline & 碑文谷公園 & 0.41 & 29.4 & 27.0 & 81.6 & 35.9 & 47.5 \\
\hline 池体 & 須藤公園 & 0.49 & 36.7 & 34.6 & 86.0 & 95.7 & 21.0 \\
\hline 他 & 教育の森公園 & 0.72 & 30.9 & 27.0 & 69.9 & 54.3 & 8.5 \\
\hline & 柳原千草公園 & 1.79 & 36.6 & 27.2 & 58.7 & 90.2 & 11.4 \\
\hline & 神明水 & 1.82 & 32.5 & 27.4 & 68.5 & 78.6 & 15.2 \\
\hline \multirow{4}{*}{ 滝 } & 成田かつぱ公園 & 1.81 & 33.1 & 28.0 & 87.1 & 96.3 & 23.3 \\
\hline & 希望ヶ丘公園 & 14.60 & 30.8 & 26.0 & 83.7 & 54.7 & 0.9 \\
\hline & 滝野川公園 & 20.50 & 31.6 & 31.5 & 77.0 & 79.7 & 9.7 \\
\hline & 名主の滝公園 & 20.70 & 35.3 & 27.0 & 88.3 & 90.3 & 16.8 \\
\hline \multirow{7}{*}{ 流 } & 古石場公園 & 0.21 & 27.6 & 24.5 & 56.6 & 32.6 & 38.5 \\
\hline & 東山貝塚公園 & 0.72 & 29.0 & 27.0 & 77.4 & 74.2 & 8.6 \\
\hline & 音無親水公園 & 0.80 & 29.5 & 28.0 & 88.7 & 89.3 & 17.3 \\
\hline & 三田丘の上公園 & 0.89 & 29.9 & 26.0 & 60.7 & 34.2 & 15.0 \\
\hline & 永福中央公園 & 1.08 & 29.9 & 26.0 & 73.1 & 34.7 & 6.3 \\
\hline & 和泉 $2 丁$ 目公園 & 1.20 & 33.7 & 30.2 & 77.3 & 43.7 & 2.6 \\
\hline & 昭栄公園 & 1.81 & 31.3 & 18.0 & 77.6 & 65.3 & 3.6 \\
\hline \multirow{7}{*}{$\begin{array}{l}\text { 噴 } \\
\text { 水 }\end{array}$} & 埠頭公園 & 0.55 & 31.5 & 28.2 & 73.4 & 28.1 & 12.3 \\
\hline & 竪川公園 & 0.67 & 33.4 & 29.2 & 65.2 & 16.0 & 1.8 \\
\hline & 箱崎公園 & 1.06 & 35.3 & 25.9 & 64.9 & 39.4 & 1.0 \\
\hline & 三河台公園 & 1.72 & 34.1 & 28.0 & 76.9 & 39.9 & 10.2 \\
\hline & 済美公園 & 1.82 & 31.0 & 27.0 & 90.5 & 77.6 & 8.9 \\
\hline & 大塚公園 & 2.43 & 30.0 & 24.0 & 75.3 & 75.8 & 13.8 \\
\hline & 大森貝塚公園 & 16.80 & 33.0 & 29.0 & 73.2 & 67.3 & 1.5 \\
\hline
\end{tabular}

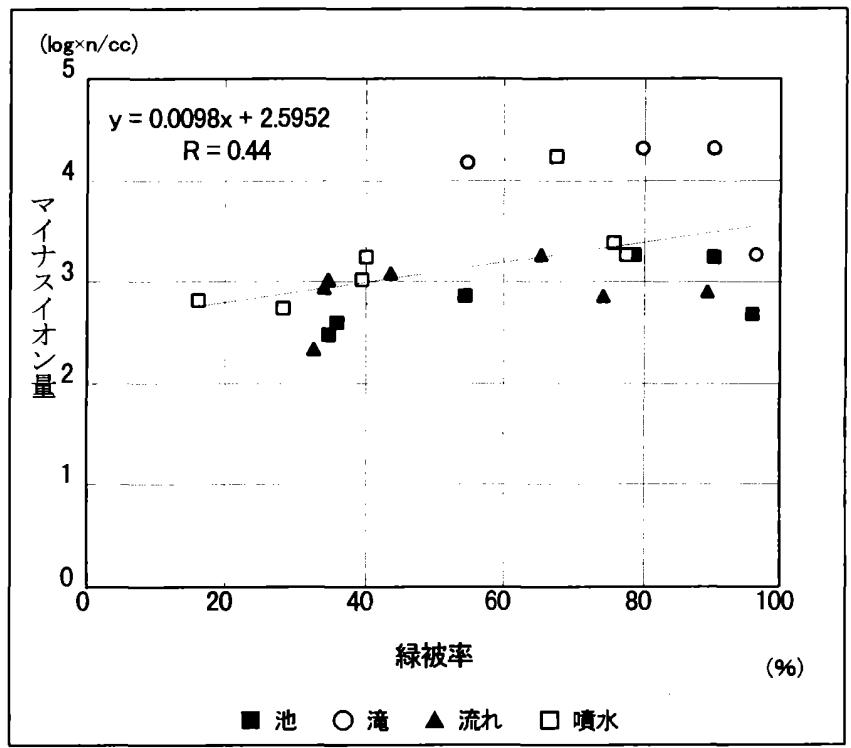

図一３ マイナスイオン量と緑被率

図一6 に示寸第IV因子「水の規模性」と水面積の関係について は，水面率が高くなるほど「池」や「流れ」といった形態で、因 子階級も高くなる傾向がみられる。なお、第而因子「空間性」に ついては物理的要因との関連はみられない。 


\section{7.おわりに}

本研究で得られた結果をまとめると以下に示すようになる。

(1)水景施設及びその周辺環境に対する心理構造は，4因子軸で践成 され、水景施設の水については「水の審美性」「水の規模性」の 2つが認識されている。

(2)マイナスイオンの存在量は水景施設の形態により大きな差異が見 られたが、最も存在量の多い形態は「滝」であり、水の動きが発 生量に影響していることが分かる。

(3)心理構造と物理的要因の関連性については,「自然性」と「緑被 率」「水の審美性」と「マイナスイオン存在量」、水の規模性」 と「水面率」の間に関連性がみられた。

本研究では、水景施設のマイナスイオン発生量の把握を行うとと もに、このマイナスイオンの発生量と利用者としての人々が水から 受ける心理的な感受度との間の関連性を明らかにしようと考えた。 そのため、種々ある水景施設の形態を大別して計測調査を行い、そ れぞれ形態によってマイナスイオン発生量に違いのあることを明ら かにした。また、水辺周辺の環境（植生など）によってマイナスイ オンの存在量が影響を受けることもある程度理解できた。一方、マ イナスイオン量と心理量の関係については明確な相関性は得られな かったもが、形態に依存しつ何らかの関連があることを示唆した。

今回の計測調査の結果は、水辺におけるマイナスイオン量と心理 量の関俰把握の研究が緒についたことを示すものであり、今後は、 実験室など安定した環境における、生理的・心理的影響や水景施設 でのマイナスイオンの発生条件に関するデータを蓄積し、それらを 総合的に捉える必要があると思われる。

*注 1 : マイナスイオンと注空気中を漂う微粒子に帯電が生じた物の総称である 大きさや形状は様々で、带電り原因としては紫外線、宇宙線、風による移動、電 離放射線、加熱など様々な要因がある これまで空気污染指標の一つとして経験 的に捉えられ、マイナスの電荷を持ったものけ呼吸器疾患や作業効率ひ向上等け 生理的・心理的効果があるという報告がある，水辺空間で汢水け飛沫が主な発生 源になると考えられる（参考文献6）・7）

\section{口参考文献}

1) 鈴木信宏 他 : 水音評価と周辺音別にみた実験的水音環境 評価 日本建築学会 技術報告集 1996.3

2) Kruger. A. P\&Reed. E. J : Biological impact of small air ions Science vol. 193. 1976, pl209

3）島田洋他 : 大気中におけるイオン濃度実測 日本建築学会大会学術講演梗概集 1990. 9

4) 島田洋他 : 大気中におけるイオン濃度実測 そひ 2 高原・郊外・市街における 春・夏・秋のイオン浱度の奏测 日本建築学会大会学術講演梗概集 1991.9

5）畔柳昭雄 他 : 東京都区部における親水公園し)形態・機能特性に関小万調査研 究 第 7 回環境情報科学論文集 1994

6) Hawkins. H. H\&Baker. T : Air ions and human performance Ergonomics voll. 21. 1978, p273

7)C. A. Laws : Air ions in the working enoviorment The heat ing and Ventialating Engineer 1982.5

8)畔柳眧雄 他 : 都市住民心意識から捉えた水辺空間し持つオーブンイ゙ー人効果に関小 万研究 その1、そ(2、そい 3 日本建築学会計画系論文集 第 464 号 1994 年 9)高橋幹二：応用エアロゾル工学 美蜸堂 1881

10)斉藤平藏 : 建築気候 共立出版 1974

11) 新建篫体系編集委員会 : 新建築学大系 11 彰国社 1982

12) 東京都建設局 : 東京都公園調書 東京都 1997

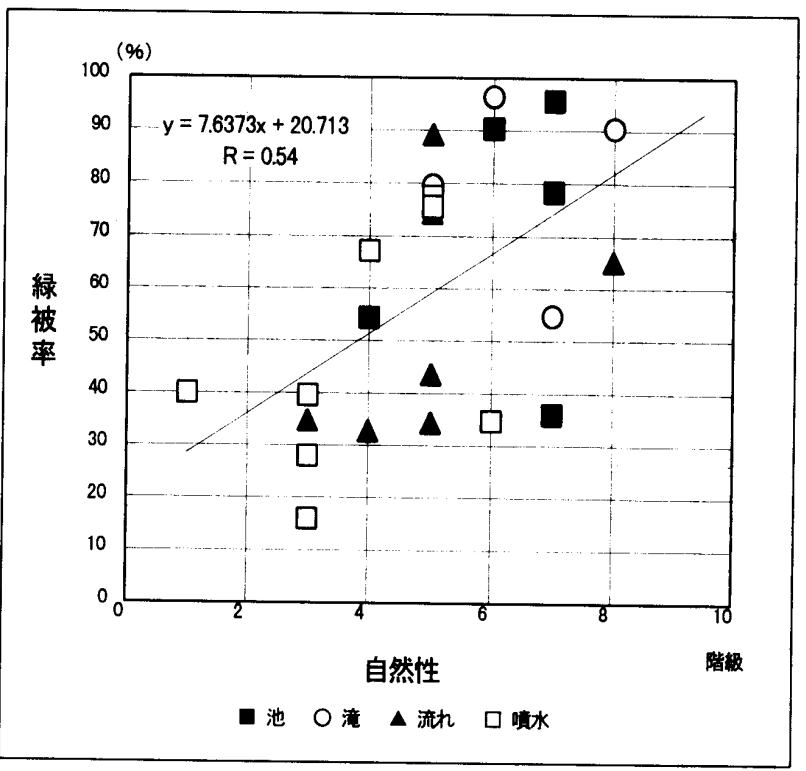

図-4 緑被率と第 I 因子（自然性）

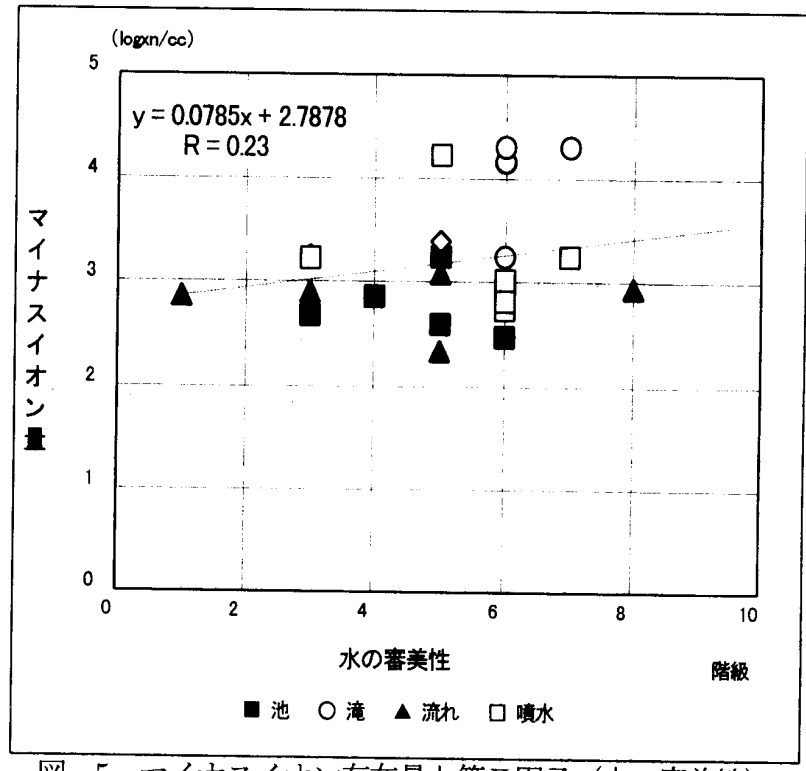

図－5 マイナスイオン存在量と第 П因子（水の審美性）

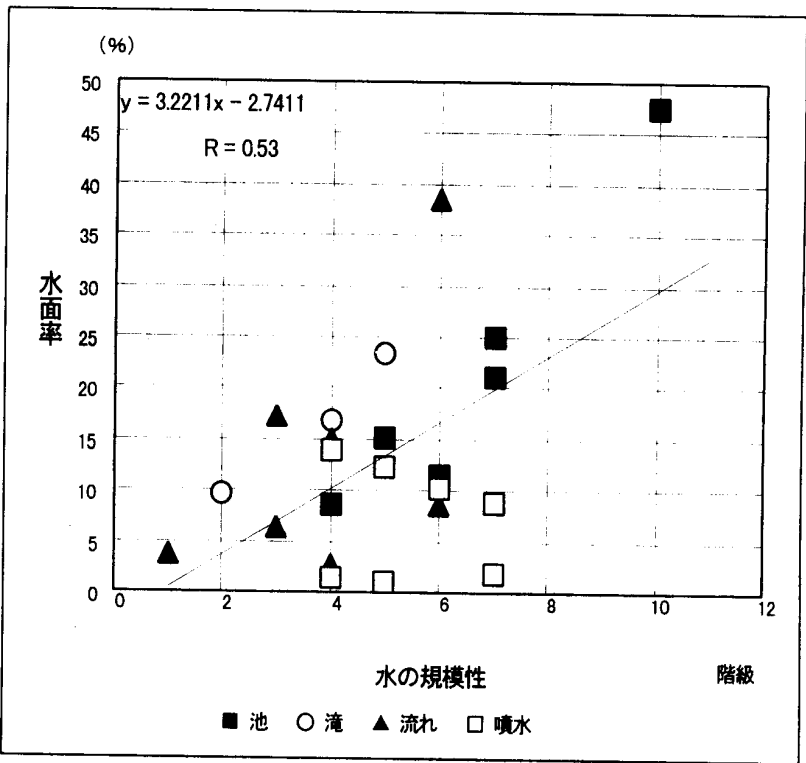

図一6 水面率と第IV因子（水の規模性）

[1998年 3 月23日原稿受理 1998年 7 月 8 日採用決定］ 